\title{
Oncophora melanocephala (Nematoda, Camallanidae) from the chub mackerel, Scomber japonicus (Teleostei, Scombridae), caught off Madeira Island (Portugal)
}

\author{
Graça Costa $^{1 *}$, Nélio Freitas ${ }^{1}$, Miguel A.A. Pinheiro de Carvalho', \\ Egberto Melo-Moreira ${ }^{1}$ and Mark C. Rigby ${ }^{2}$

\begin{abstract}
${ }^{1}$ CEM, Centro de Estudos da Macaronésia, Campus da Penteada, 9000-390 Funchal, Portugal; ${ }^{2}$ Marine Science Institute, University of California, Santa Barbara, California 93106-6150; Parsons, 406 West South Jordan Parkway, Suite 300,
\end{abstract} \\ South Jordan, UT 84095, USA
}

\begin{abstract}
While investigating the nematode parasites of commercial fish caught off the coast of Madeira Island (Atlantic Ocean, Portugal), we collected five specimens of Oncophora melanocephala (Rudolphi, 1819) (Nematoda, Camallanidae) infecting the chub mackerel Scomber japonicus Houttuyn. This is the first record of O. melanocephala from chub mackerel and a new geographic record. Four additional larval specimens with developing buccal capsules were found in the chub mackerel examined.
\end{abstract}

\section{Keywords}

Camallanid nematodes, Oncophora melanocephala, fish, Scomber japonicus, Madeira Island

\section{Introduction}

The chub mackerel Scomber japonicus (Pisces, Scombridae) supports an important commercial fishery in Madeira Island, Portugal. This fish species has a widespread geographic distribution encompassing the Atlantic, Indian, and Pacific Oceans, as well as the adjacent seas (Collette and Nauen 1983). Previous authors have reported the occurrence of approximately 30 species of helminths in the visceral cavity, intestines, stomach, and gills of this fish (Costa et al. 2007, Oliva et al. 2008). Among the helminths parasitizing this fish species, anisakid nematodes are common and are represented by several species belonging to the genera Anisakis (Dujardin, 1845), Hysterothylacium (Ward et Magath, 1917), Contracaecum (Railliet et Henry, 1912), and Raphidascaris (Railliet et Henry, 1915).

During a survey of parasites of the chub mackerel caught off the coast of Madeira, we found a camallanid nematode provisionally assigned to the genus Oncophora (Diesing, 1851) (Nematoda, Camallanidae) (see Oliva et al. 2008). Camallanid nematodes are gastrointestinal parasites of fishes and other aquatic vertebrates (Rigby 1999). Transmission to the definitive host can be accomplished in two ways: (1) directly, through infected copepods or other crustaceans infected with the third larval stage or (2) through the ingestion of planktivorous fish, which accumulate nematode larvae, thereby acting as paratenic hosts, in which the larvae can reach the fourth stage (Anderson 2000). Four genera of camallanids are known from marine fishes, namely Oncophora, Camallanus (Railliet et Henry, 1915), Spirocamallanus (Olsen, 1952) and Procamallanus (Baylis, 1923) (Vicente and Santos 1972, Rigby 1999). In the present study, we provide evidence that the camallanid found in chub mackerel caught off the coast of Madeira Island belongs to the species Oncophora melanocephala, based on light and scanning electron microscopy observations.

\section{Materials and methods}

One hundred and fifty one chub mackerel, Scomber japonicus, caught off the coast of Madeira Island, Atlantic Ocean $\left(33^{\circ} 7^{\prime} 30^{\prime \prime}-32^{\circ} 22^{\prime} 20^{\prime \prime} \mathrm{N}\right.$ and $\left.16^{\circ} 16^{\prime} 30^{\prime \prime}-17^{\circ} 16^{\prime} 38^{\prime \prime} \mathrm{W}\right)$ were purchased at the local fish market, from November 2004 to March 2005. After capture by fishermen, all fish were placed on ice until dissection. Fish ranged in length (total length) from 23 to $40 \mathrm{~cm}$. Fish were dissected and examined for the presence of nematodes in the visceral cavity and digestive tract, under a Zeiss Stemi 2000 C stereomicroscope, equipped with a Sony digital camera. Recovered nematodes were fixed in hot $70 \%$ ethanol, cleared in lactophenol, and mounted in glycerol jelly (Berland 2005). Morphological study and identification was 
performed using a Zeiss Axioplan Photomicroscope, equipped with DIC optics and a MC- 80 camera. Measurements of morphological features were made with the aid of an ocular micrometer. Prevalence, intensity and abundance were calculated following Bush et al. (1997). Two individual Oncophora melanocephala were post fixed in 1\% osmium tetroxide, dehydrated in graded ethanol series, critical point dried (JEOL JFC 1100) coated with gold-palladium (SPI sputter coater) and examined with a JEOL JSM-6301F scanning electron microscope (SEM).

\section{Results}

Five nematodes were found in the body cavity of the chub mackerel examined. The worms were fusiform in shape. When fresh, the worms were white in colour, except for the buccal capsule, which was dark brown. Males were 8.06-9.62 mm long $(\mathrm{n}=2)$ and juvenile females were $12.06-14.09 \mathrm{~mm}$ long $(\mathrm{n}=2)$. The buccal capsule was composed of four prominent parts, as follows: (1) two lateral valves, (2) two dorso-ventral tridents, (3) a basal ring, and (4) a colourless sclerotized cup connecting basal ring to oesophagus (Fig. 1). The tridents extended well past the posterior end of the buccal capsule (Fig. 1). Tridents were $150 \mu \mathrm{m}$ in total length (i.e., from base to dis-

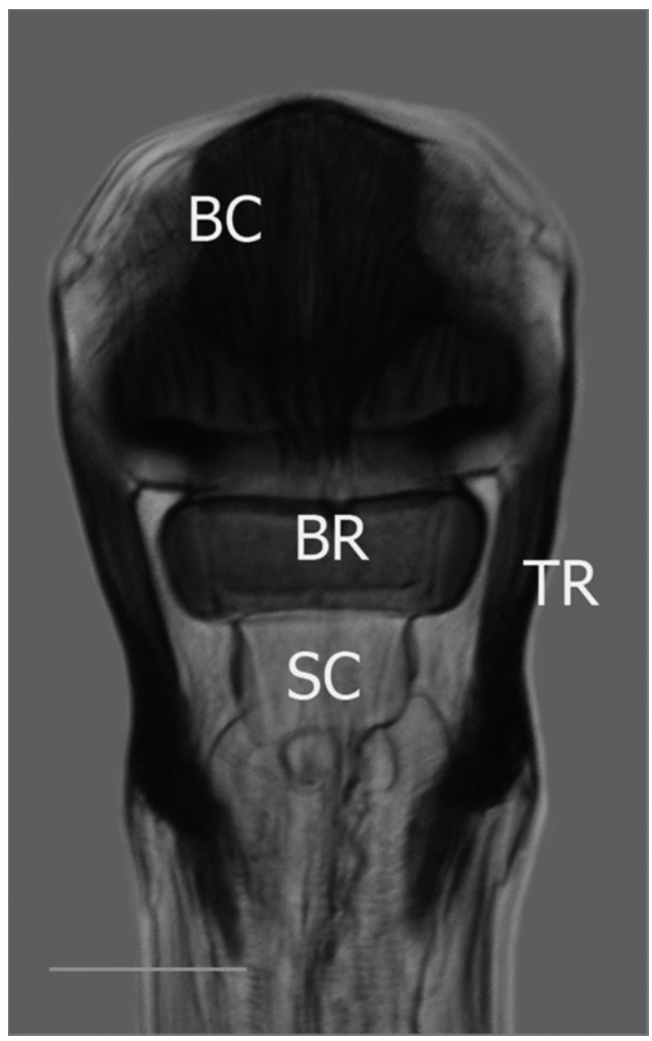

Fig 1. SEM micrograph of lateral view of cephalic extremity of $\mathrm{On}$ cophora melanocephala from Scomber japonicus, showing the buccal capsule (BC), basal ring (BR), sclerotized cup (SC) and tridents (TR). Scale bar $=43 \mu \mathrm{m}$

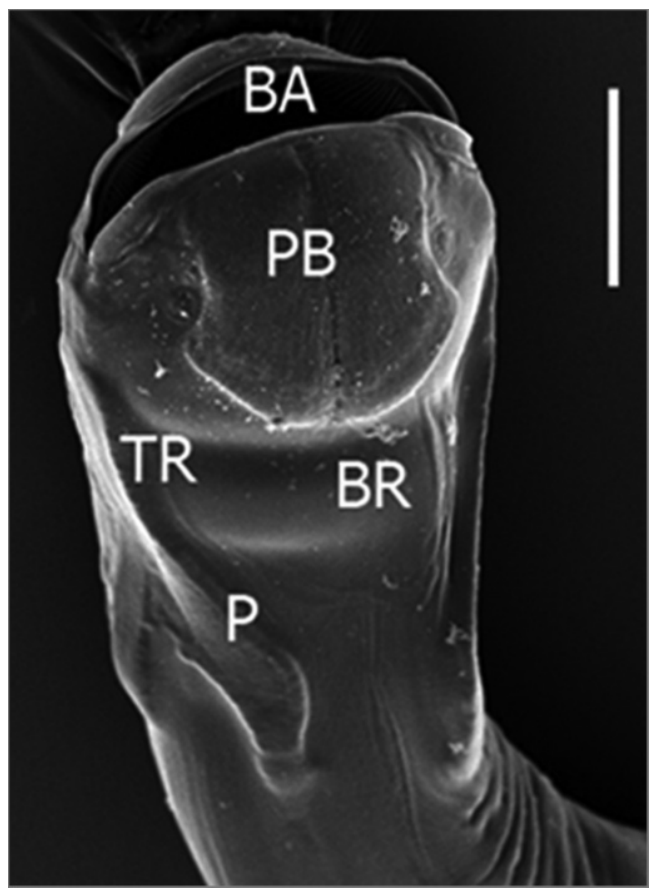

Fig 2. SEM micrograph of cephalic end of Oncophora melanocephala showing peribuccal shields (PB), basal ring (BR), tridents (TR) with prongs $(\mathrm{P})$ and slit-like buccal aperture $(\mathrm{BA})$. Scale bar $=50 \mu \mathrm{m}$

tal end of prongs), with lateral prongs measuring $70 \mu \mathrm{m}$ in length and the central prong measuring $63 \mu \mathrm{m}$. In one female, the two laterals were $63 \mu \mathrm{m}$, and the central prong was $75 \mu \mathrm{m}$ long, while in two males, the lateral prongs $56 \mu \mathrm{m}$ and the central prong was $73.5 \mu \mathrm{m}$ long. The mouth was a slit-like opening between the two valves of the buccal capsule, each bearing two rounded cephalic papillae (Fig. 2). The buccal capsule had about 28 ridges at in the anterior margin in males $(n=1)$ and 38 in females $(n=1)$, with the number of ridges decreasing posteriorly. The buccal capsule ridges are readily visible using SEM through the open mouth of the worm (Fig. 3). Two peribuccal shields were observed on the anterior end of each valve, extending at least two-thirds of the length of the buccal capsule (Fig. 2). The muscular oesophagus was 980-1110 $\mu \mathrm{m}$ in males $(\mathrm{n}=2)$ and $1120-1320 \mu \mathrm{m}$ in females $(\mathrm{n}=2)$, while the glandular oesophagus measured $960-1040 \mu \mathrm{m}$ in males $(\mathrm{n}=2)$ and $1110-1310 \mu \mathrm{m}$ in females $(\mathrm{n}=2)$. Males had 7 pairs of preanal and five pairs of postanal caudal papillae. The length of the larger spicule was $554 \mu \mathrm{m}(\mathrm{n}=1)$. The male tail was conical in shape, measuring $53.3 \mu \mathrm{m}(\mathrm{n}=1)$, and without papilla-like protrusions at the posterior extremity. The female vulva protruded and the opening was characterized by elevated and darkened folding. Female tail was conical, measuring 200 $\mu \mathrm{m}$ long $(\mathrm{n}=1)$ with 2 visible minute papilla-like protrusions at the posterior extremity. Based on the characteristic morphological features of the buccal capsule, morphology of the tridents, and the number and disposition of male caudal papillae, we identify our specimens from the chub mackerel off the coast of Madeira Island as Oncophora melanocephala. The 


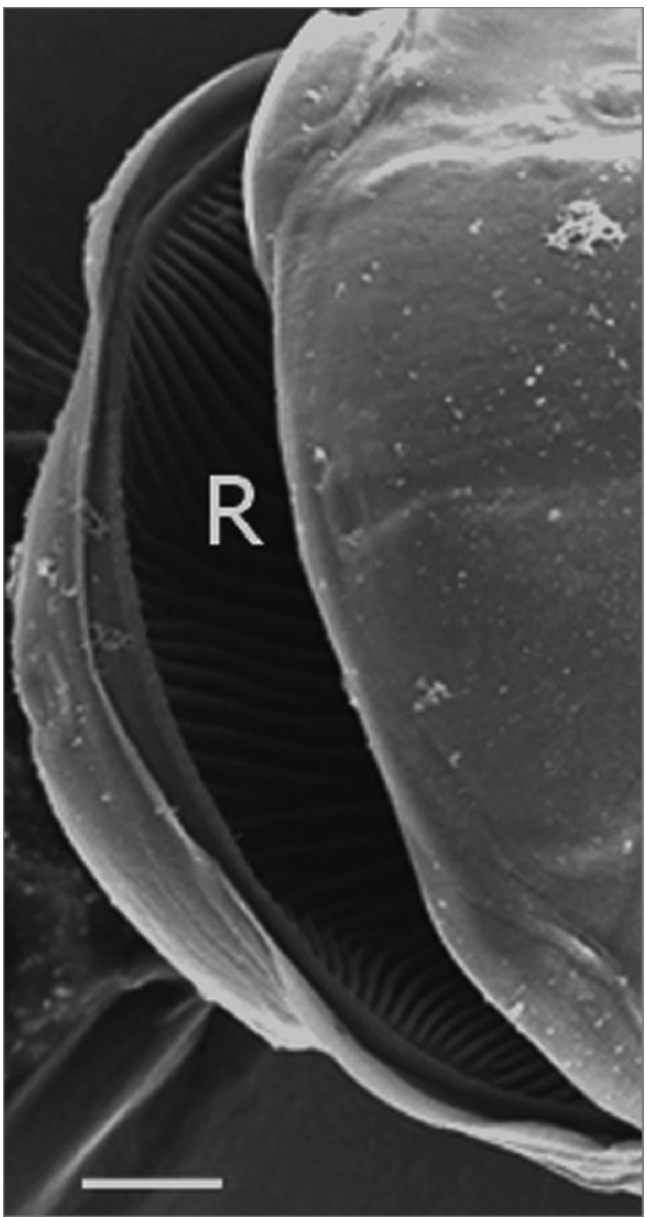

Fig 3. SEM micrograph of lateral view of Oncophora melanocephala showing mouth opening with inner ridges $(\mathrm{R})$. Scale bar $=10 \mu \mathrm{m}$

prevalence of $O$. melanocephala in chub mackerel was 3.3\% $(\mathrm{n}=151)$. Mean intensity and mean abundance values were low at 1.64 and 0.12 , respectively.

\section{Discussion}

Apparently, Oncophora melanocephala is the only species of the genus described to date (Moravec et al. 1999). Its distribution includes the Atlantic Ocean, Gulf of Mexico and the Mediterranean. This camallanid nematode has previously been reported from the following marine fish:

Northwestern Atlantic: Sword fish, Xiphias gladius Linnaeus) (Hogans et al. 1983, Bunkley-Williams and Williams 1996, Castro-Pampillón et al. 2002).

"North Sea and Mediterranean" (Bunkley-Williams and Williams 1996): Atlantic mackerel, Scomber scombrus Linnaeus; Atlantic bonito, Sarda sarda Bloch; bluefin, Auxis rochei rochei (Risso); frigate tuna, Auxis thazard Lacepède; bluefin tuna, Thunnus thynnus Linnaeus.

Mediterranean: Various Scombridae as Cucullanus melanocephalus, synonym Trichocephalus gibbosus (Rudolphi,
1819); bluefin tuna, Thunnus thynnus Linnaeus (Mladineo 2006a, b; Nowak et al. 2006; Mladineo et al. 2008); sword fish, Xiphias gladius Linnaeus (Damiano et al. 2006).

Gulf of Mexico: Atlantic blue marlin, Makaira nigricans Lacepède (Bunkley-Williams and Williams 1996); yellowfin tuna, Thunnus albacares Bonnaterre (Bunkley-Williams and Williams 1996); queen snapper, Etelis oculatus Valenciennes (Rodriguez 2004).

Gulf of Guinea: Albacore (yellowfin) tuna, Thunnus albacares Bonnaterre (Baudin-Laurencin 1971, 1972); males were described as O. albacarensis (Baudin-Laurencin 1972).

Brazil: Atlantic big-eye, Priacanthus arenatus Cuvier (Pinto et al. 1988, Tavares et al. 2001); tuna (Thunnus thynnus, T. albacares, T. atlanticus, Auxis thazard) (Moravec et al. 1999); Atlantic bonito, Sarda sarda (Bloch) (Alves and Luque 2006).

Moreover, Rigby (1999) considers that the species $\mathrm{Ca}$ mallanus aotea Slankis et Korotaeva, 1974, should be transferred to the genus Oncophora, thus extending the geographic range of Oncophora to the Pacific. Moravec et al. (1999) concurred that $\mathrm{C}$. aotea bears a strong resemblance to O. melanocephala but stated that $C$. aotea should be re-examined before being transferred to Oncophora. However, type specimens are not available.

In our specimens, we observed 28 to 38 buccal capsule ridges, which is much greater than the 22 ridges reported by Moravec et al. (1999). Although Petter (1979) stated that the number of buccal capsule ridges in the genus Camallanus may indicate evolutionary affinities, Rigby and co-authors have reported that the number of ridges depends on the position of the capsule where the ridges were counted in Camallanus and other Camallaninae (Rigby et al. 1998, 2008; Sharma et al. 2002). As reported above, the number of buccal capsule ridges, in our specimens of $O$. melanocephala, were greatest at the anterior margin and decreased posteriorly.

Our specimens from chub mackerel were smaller than those described by Moravec et al. (1999) from tuna. Moreover, females did not show the enlargement of the body at its posterior part as seen in Moravec et al. (1999), a characteristic of gravid females of this genus. Most likely, our specimens were juvenile specimens not yet fully grown and will become fully developed in a later phase.

Acknowledgements. Financial support for the present study was provided by the Portuguese Foundation for Science and Technology (FCT/POCTI) through their pluriannual programs.

\section{References}

Alves D., Luque J.L. 2006. Ecologia das comunidades de metazoários parasitos de cinco espécies de escombrideos (Perciformes: Scombridae) do litoral do Estado do Rio de Janeiro, Brasil. Revista Brasileira de Parasitologia Veterinária, 15, $167-181$.

Anderson R.C. 2000. Nematode Parasites of Vertebrates: their development and transmission. 2nd Edition. CABI Publishing, Wallingford, UK, $650 \mathrm{pp}$. 
Baudin-Laurencin F. 1971. Oncophora melanocephala (Rud., 1819) n. comb., nématode Camallanidae, parasite du thon albacore Neothunnus albacares. Bulletin du Muséum National d'Histoire Naturelle, 2 Sér., 42, 984-988.

Baudin-Laurencin F. 1972. Oncophora albacarensis n. sp. (Nématode, Camallanidae) parasite du thon Albacore Thunnus albacares. Bulletin du Muséum National d'Histoire Naturelle, 3 Sér., 96, Zoologie, 75, 1329-1331.

Berland B. 2005. Whole mounts. Institute of Oceanography, Kustem, Malaysia, $54 \mathrm{pp}$.

Bunkley-Williams L., Williams E.H. 1996. Parasites of offshore big game fishes of Puerto Rico and the Western Atlantic. Antillean College Press, Mayaguez, Puerto Rico, 383 pp.

Bush A.O., Lafferty K.D., Lotz J.M., Shostak A.W. 1997. Parasitology meets ecology on its own terms: Margolis et al. revisited. Journal of Parasitology, 83, 575-583. DOI: 10.2307/328 4227.

Castro-Pampillón J.A., Soto-Buá M., Rodríguez-Domínguez H., Mejuto-Garcia J., Árias-Fernández C., Garcia-Estévez J.M. 2002. Selecting parasites for use in biological tagging of the Atlantic swordfish (Xiphias gladius). Fisheries Research, 59, 259-262. DOI: 10.1016/S0165-7836(02)00008-5.

Collete B.B., Nauen C.E. 1983. Scombrids of the world. FAO Fisheries Synopsis 125, Rome, Italy, 137 pp.

Costa G., Freitas N., Dellinger T.H., MacKenzie K. 2007. Gill monogeneans of the chub mackerel, Scomber japonicus from Madeiran waters of the Atlantic Ocean, Portugal. Journal of Helminthology, 81, 33-38. DOI: 10.1017/S0022149X0720 7333.

Damiano S., Mattiucci S., Garcia A.C., Santos M.N., Nascetti G. 2006. Parassiti come "biological tags" per la caratterizzazione degli stocks ittici di pesce spada (Xiphias gladius L.) in acque europee. In: 16th Meeting of the Italian Society of Ecology, Italy, $1-4$.

Hogans W.E., Brattey J., Uhazy L.S. 1983. Helminth parasites of swordfish (Xiphias gladius L.) from the Northwest Atlantic Ocean. Journal of Parasitology, 69, 1178-1179.

Mladineo I. 2006a. Check list of the parasitofauna in Adriatic Sea cage-reared fish. Acta Veterinaria (Beograd), 56, 285-292.

Mladineo I. 2006b. Parasites of Adriatic cage reared fish. Acta Adriatica, 47, 23-28.

Mladineo I., Zilic J., Cankovic M. 2008. Health survey of Atlantic tuna, Thunnus thynnus (Linnaeus, 1758), reared in Adriatic cages from 2003 to 2006. Journal of the World Aquaculture Society, 39, 281-289. DOI: 10.1111/j.1749-7345.2008.00156.X.

Moravec F., Kohn A., Santos L.A. 1999. New data on Oncophora melanocephala (Nematoda: Camallanidae), a little known parasite of scombrid fishes. Parasite, 6, 79-84.

Nowak B., Mladineo I., Aiken H., Bott N., Hayward C. 2006. Results of health surveys of two species of farmed tuna: southern bluefin tuna (Thunnus maccoyii) in Australia and northern bluefin tuna (Thunnus thynnus) in the Mediterranean. Bulletin of the European Association of Fish Pathologists, 26, 38-42.
Oliva M.E., Valdivia I.M., Costa G., Freitas N., Pinheiro de Carvalho M.A., Sánchez L., Luque J.L. 2008. What can metazoan parasites reveal about the taxonomy of Scomber japonicus Houttuyn in the coast of South America and Madeira Islands? Journal of Fish Biology, 72, 545-554. DOI: 10.1111/j.10958649.2007.

Petter A.J. 1979. Essai de classification de la sous-famille dês Camallaninae (Nematoda, Camallanidae). Bulletin du Muséum National d'Histoire Naturelle, Paris, 4' Sér., 1, Sect. A, 4, 219 239.

Pinto R.M., Vicente J.J., Noronha D., De Fábio S.P. 1988. Redescription of Oncophora melanocephala (Rudolphi, 1819) Baudin-Laurencin, 1971 (Nematoda, Camallanidae). Memórias do Instituto Oswaldo Cruz, 83, 233-237.

Rigby M.C. 1999. The Camallanidae (Nematoda) of Indo-Pacific fishes: taxonomy, ecology and host-parasite coevolution. In: (Eds. B. Seret and J.Y. Sire) Proceedings of the 5th Indo-Pacific Fish Conference, Nouméa, 1997. Societé Française de Ichthyologie, Paris, 633-644.

Rigby M.C., Adamson M.L., Deardorff T.L. 1998. Camallanus carangis Olsen, 1954 (Nematoda: Camallanidae) reported from French Polynesia and Hawaii with a redescription of the species. Journal of Parasitology, 84, 158-162. DOI: $10.2307 / 3284548$.

Rigby M.C., Sharma R.S.K., Hechinger R.F., Platt T.R., Weaver J.C. 2008. Two new species of Camallanus (Nematoda: Camallanidae) from freshwater turtles in Queensland, Australia. Journal of Parasitology, 94, 1364-1370. DOI: 10.1645/GE1504.1.

Rodriguez L.J.B. 2004. Metazoan parasites of snappers, Lutjanidae (Pisces) from Puerto Rico. MSc Thesis, University of Puerto Rico, $191 \mathrm{pp}$.

Sharma R.S.K., Rigby M.C., Sumita S., Sani R.A., Vidyadaran M.K., Jasni S., Dailey M.D. 2002. Redescription of Serpinema octorugatum (Baylis, 1933) (Nematoda: Camallanidae) from the Malayan box turtle Cuora amboinensis (Daudin) (Chelonia: Bataguridae). Systematic Parasitology, 53, 19-28. DOI: 10.1023/A:1019997922052.

Slankis A.Ya., Korotaeva V.D. 1974. Three new species of nematodes of the genus Camallanus (Nematoda, Spirurida) from fishes of the Australo-New Zealand region. Izvestiya Tikhookeanskogo Nauchno-Issledovatel'skogo Instituta Rybnogo Khozyaistva i Okeanografii, 88, 124-128 (In Russian).

Tavares L.E.R., Luque J.L., Neto S.L.B. 2001. Ecologia da comunidade de metazoários parasitos do olho-de-cão Priacanthus arenatus (Cuvier, 1829) (Osteichthyes, Priacanthidae) do litoral do estado do Rio de Janeiro, Brasil. Revista Brasileira de Zoociências, 3, 45-59.

Vicente J.J., Santos E. 1972. Sobre um novo nematódeo camalanídeo parasito de peixe marinho (Nematoda, Camallanoidea). Atas da Sociedade de Biologia do Rio de Janeiro, 15, 145-147. 